Apidologie, 1978, 9 (2), 95-100.

\title{
PROGENY TESTING AND SELECTING ITALIAN QUEENS FOR BROOD AREA AND HONEY PRODUCTION
}

\author{
R. BAR-COHEN*, G. ALPERN** and R. BAR-ANAN \\ Ministry of Agriculture, department of Animal husbandry, \\ Hakirya, Tel-Aviv
}

\begin{abstract}
SUMMARY
Progeny testing of selected queens, being part of improvement project of Italian bees in Israel, was carried out between 1962 and 1974 at the Bee Breeding Apiary of the Ministry of Agriculture at Zerifin. Honey production and brood area of 562 and 499 bee colonies, respectively, were recorded.

The regression of honey production on the number of brood cells was linear without any parabolic trend, and amounted to $0.7 \mathrm{~kg}$ honey per 1000 brood cells. The regression of brood cells and honey production of daughters on brood cells of mothers was very slight and non-significant. Therefore, the fertility of Italian queens, measured by the number of brood bells, could not serve as criterion for selection for improvement of honey production. The regression of honey production of daughter queens on that of their mothers was $0.27 \pm 0.08$ showing heritability of 0.54 . The selection differential for queens (average of 13 years) was $17.5 \mathrm{~kg}$. Thus queen selection according to honey production seems to have been an effective tool for improving honey production of the Italian honey bee.
\end{abstract}

\section{INTRODUCTION}

The introduction of Italian bees into the apiaries in Israel was started in 1948 with the objective of substituting the local population of Syrian bees by a gentler and more productive race. After ten years of importation of Italian queens from the U.S., an increase of about $30 \%$ in the average honey production had been achieved. It was assumed that a project of selective breeding of Italian queens might achieve further progress in honey production. In a preliminary study based on the tests in the years 1961-1963 the heritability estimates of honey production and queen fertility were

* Present address : Tel Aviv, Akiva Arye 4.

** Present address : Tel Aviv, Brodetsky 56. 
obtained. FARRAR (1937) had suggested that the efficiency of a colony in collecting honey was correlated with its population size. The laying capability of a queen was therefore assumed to be one of the most important factors in honey production. Soller and BAR-COHEN (1967) found a moderate correlation between brood area and honey production in the spring, both in 1961-1962 and in 1962-1963 and also a good response to selection for honey production ability.

Following these results, progeny testing for two characters : number of brood cells and honey yield, was carried out for further ten years.

\section{MATERIALS AND METHODS}

Progeny tests were performed at the Bee Breeding Apiary of the Ministry of Agriculture at Zerifin. The hives of the tested colonies were arranged in groups of four, each facing different directions in order to reduce drifting, which may have a considerable effect on honey production of individual colonies and distort tests (FRESNAYE, 1963).

Stores of tested colonies were equalized in the autumn, and sugar syrup was added whenever necessary. At the start of every test, in autumn, colonies of medium strength were chosen; very strong colonies or weak ones were excluded. All the colonies received similar treatment. The brood area of the colonies was measured in the first or second week of March. The length and breadth of the brood ellipse on both sides of all the combs of the nest were measured in order to evaluate the number of brood cells of each colony. The Zerifin Breeding Apiary is situated among citrus groves and the citrus blossom was almost the only nectar source in the area, so that the crop extracted at the end of the citrus honey flow was considered the annual yield of the colonies. The yield was evaluated by the net weight of honey stored in the supers and brood-nest minus the weight of last autumn's stores. The breeder queens were selected among sister queens within the groups of colonies which collected the highest average crop in the apiary. Besides the yield in the choice of breeder queens attention was paid to gentleness and uniformity of body coloration of worker bees. In the spring 5-15 daughter queens were reared from each breeder queen. The virgin queens were mated at an isolated mating station free of other colonies in a radius of 5 to $6 \mathrm{~km}$ and very few colonies in the outskirts.

\section{RESULTS}

Annual yields and number of cells are presented in Table 1. It shows a general increase in honey production with a few setbacks in years of poor pasture.

Table 2 presents the phenotypic association within years between number of brood cells and honey production. The regression of honey production on the number of brood cells was linear without any parabolic trend; on average, 1000 brood cells increased the yield by $0.7 \mathrm{~kg}$. Thus selection by one standard deviation would increase honey production by $4.6 \mathrm{~kg}(0.73 \times 6336)$. The standard error regression was three times higher than such a selection differential. It seems therefore, that selection for a number of brood cells would not be a reliable means for increasing honey production. Table 3 portrays the association between the honey yields and number of brood cells of pairs of dam-daughter queens. 
TABL. 1. - Annual mean honey yield and number of brood cells per tested colony.

\begin{tabular}{c|c|c|c|c}
\hline \multirow{2}{*}{} & \multicolumn{2}{|c|}{ Honey yield } & \multicolumn{2}{c}{ Brood cells } \\
\cline { 2 - 5 } & No colonies & $\mathrm{kg}$ & No colonies & Thousand cells \\
\cline { 2 - 5 } 1962 & & & & \\
1963 & 28 & 33.9 & 2 & 29.5 \\
1964 & 21 & 27.2 & 21 & 25.0 \\
1965 & 16 & 43.9 & 15 & 21.2 \\
1966 & 18 & 40.9 & 18 & 17.8 \\
1967 & 34 & 49.9 & 12 & 22.9 \\
1968 & 36 & 53.8 & 36 & 27.9 \\
1969 & 46 & 41.8 & 46 & 29.8 \\
1970 & 78 & 39.9 & 77 & 28.7 \\
1971 & 84 & 48.9 & 81 & 25.8 \\
1972 & 72 & 56.8 & 66 & 31.9 \\
1973 & 60 & 57.3 & 57 & 33.8 \\
1974 & 33 & 65.3 & 32 & 32.4 \\
Total & 36 & 43.1 & 36 & 28.2 \\
and & & & & \\
Average & 562 & 48.0 & & \\
\hline
\end{tabular}

TABL. 2. - Phenotypic correlations between number of brood cells and honey production

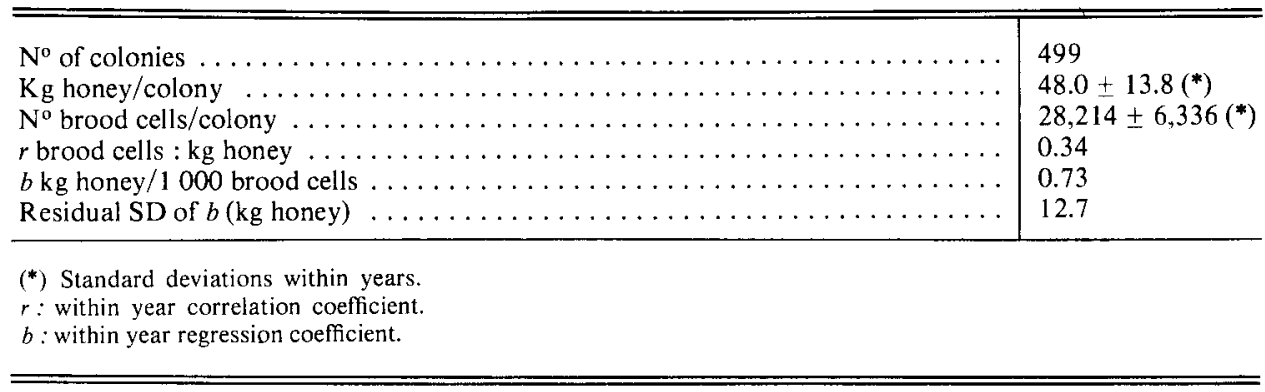

TABL. 3. - Association between dam and daughter production.

\begin{tabular}{|c|c|c|c|c|}
\hline & \multicolumn{2}{|c|}{$\mathrm{Kg}$ honey } & \multicolumn{2}{|c|}{$\mathrm{N}^{\circ}$ of brood cells } \\
\hline & Dams & Daughters & Dams & Daughters \\
\hline $\begin{array}{l}\mathrm{N}^{o} \text { of colonies } \ldots \ldots \ldots \ldots \\
\text { Selection differential } \ldots \ldots \ldots \ldots \ldots \ldots \ldots \\
\text { Standard deviation } \ldots \ldots \ldots \ldots \ldots \ldots \ldots \ldots \\
r \text { dams } \text { daughters } \ldots \ldots \ldots \ldots \ldots \ldots \ldots \ldots \\
b \text { daughters/dams } \ldots \ldots \ldots \ldots \ldots \ldots \ldots \\
\mathrm{H}^{2} \ldots \ldots \ldots \ldots \ldots \ldots \ldots \ldots \ldots\end{array}$ & \multicolumn{2}{|c|}{$\begin{array}{c}0.15 \\
0.27 \pm 0.08 \\
0.54\end{array}$} & \multicolumn{2}{|c|}{$\begin{array}{c}0.05 \\
0.05 \pm 0.05 \\
0.10\end{array}$} \\
\hline
\end{tabular}

$\mathrm{h}^{2}$ : heritability. 
The selection differential for honey production among mother-queens was $17.5 \mathrm{~kg}$, which are $-1.28 \mathrm{SD}$. The correlation between dam-daughter honey yield was 0.15 and the regression of daughter on dam production was 0.27 , giving an heritability estimate of 0.54 . The selection differential for brood cells among breeder queens was 4000 cells, but the regression of daughters on mothers was very small $(0.05)$ and nonsignificant. Thus, selection based on the number of brood cells would hardly increase fertility. The regression of daughters' production on the number of brood cells of their dams was not significant : $0.10 \pm 0.09 \mathrm{~kg}$ honey of daughter per 1000 brood cells of dams. It may be concluded that selection for fertility would have no effect on honey production.

\section{DISCUSSION}

Our preliminary studies indicated a close relation between the brood area and the spring honey production. It appeared that highly fertile queens ought to be preferred. However, LAVIE and FRESNAYE have already observed that in some years, colonies with a medium brood area yielded more honey than colonies with a large area (LouveauX, 1967). Our own observations have shown that over a period of 13 consecutive years, even on a within-year basis, the correlation between fertility of the queen and the yield of her colony was only moderate. The discrepancy between these results and those obtained in other studies and in our preliminary study seems to be due to the interaction between the number of brood cells and environmental factors on honey production, E.G. : in a good year strong colonies will take full advantage of their numerical superiority, but in a bad season they will consume a considerable part of the collected crop and will be prone to swarming, while colonies of medium strength will consume less and will store more honey.

Low heritability of fertility in bees in relation to their honey production is in accordance with results in cattle and sheep. Moreover, fertility in bees is a phenotypic characteristic of the queen, while the honey crop is a function of thousands of worker bees and could be considered a progeny test of the phenotypic trait of the queen for productive activity. The heritability value of 0.54 for honey production based on the regression of daughters on dams provides a good basis for selection and progress. This value was in accordance with our preliminary study, but slightly higher than the estimate obtained by PIRCHNER et al (1962). The correlation between dam and daughter production was relatively small as an effect of the severe selection among the dams. This low value indicates that it is hardly predictable which among the selected queens will prove to be the best and that continuous testing and selecting is necessary for improvement.

\section{CONCLUSIONS}

Information gathered from testing the progeny of Italian queens for 13 years proved that selecting breeder queens on the yield of their dams was an effective means 
for genetic progress in honey production; on the other hand, the selection for higher fertility of the queens seemed uneffective for increasing honey production. The selection differential among queens as average of 13 years was $17,5 \mathrm{~kg}$ honey and it was estimated that it increases the honey production ability by $4.7 \mathrm{~kg}$ annually. Mating selected queens at a breeding station within an isolated area of 5$6 \mathrm{~km}$ - although incomplete according to recent findings (H. and F. RUTTNER, 1972) could be a practical way for the improvement of breeding stock. Another advantage of mating the queens in free air by selected drones at a breeding station was the great variety of genetic stuff securing a high viability of the progeny. As a matter of fact, during 14 years of intensive breeding, no negative effects due to inbreeding had been observed.

Received in October 1977.

\section{RÉSUMÉ}

TESTS ET SÉLECTION DE LA DESCENDANCE DE REINES ITALIENNES BASÉS SUR LA SURFACE DE COUVAIN ET LA PRODUCTION DE MIEL

Dans le cadre d'un projet d'amélioration de l'abeille italienne en Israël, on a testé au Rucher d'Élevage de l'Abeille du ministère de l'Agriculture à Zerifin, la descendance de reines sélectionnées. Les tests ont été effectués dans la zone des agrumes. On a choisi au départ des colonies de même force, auxquelles on a appliqué le même traitement et des mesures pour réduire la dérive. Les reines vierges se sont accouplées dans un rucher isolé, aucun autre rucher ne se trouvant dans un rayon de 5 à $6 \mathrm{~km}$.

La production de miel et la surface de couvain de 562 et 499 colonies respectivement ont été enregistrées.

La régression de la production de miel sur le nombre de cellules de couvain est linéaire sans aucune tendance parabolique; elle atteint $0,7 \mathrm{~kg}$ de miel pour 1000 cellules de couvain. La régression du nombre de cellules de couvain et de la production de miel des filles sur le nombre de cellules de couvain des mères est très petite et non significative. La fertilité des reines italiennes, mesurée par le nombre de cellules de couvain ne peut donc pas servir de critère de sélection pour l'amélioration de la production de miel. La régression de la production de miel des reines filles sur celle de leur mère est de $0,27 \pm 0,08$ indiquant une héritabilité de 0,54. Le différentiel de sélection pour les reines (moyenne sur 13 ans) est de 17,5 kg. Ainsi la sélection des zeines d'après la production de miel parait être un moyen effectif pour l'amélioration de la production de miel de l'abeille italienne.

\section{ZUSAMMENFASSUNG}

\section{NACHKOMMENPRÜFUNG UND SELEKTION ITALIENISCHER KÖNIGINNEN NACH BRUTFLÄCHE UND HONIGERZEUGUNG}

Als Teil eines Projektes zur Verbesserung der Italienischen Biene in Israel wurde zwischen 1962 und 1974 an der Bienenzuchtstation des Landwirtschaftsministeriums in Zerifin ein Nachkommenschaftstest selektierter Königinnen durchgeführt. Die Prüfung erfolgte im Zitrusanbaugebiet. Die Völker wurden auf gleiche Ausgangsstärke gebracht und gleich behandelt, ausserdem wurden Massnahmen zur Verringerung des Verflugs getroffen. Die Jung-Königinnen waren auf einem in 5-6 km Umdreis isolierten Stand begattet worden.

Es wurden die Honigproduktion und die Brutflächen von 562, bzw. von 499 Bienenvölkern registriert. 
Die Regression der Honigproduktion auf die Zahl der Brutzellen war linear ohne jede parabolische Tendenz; sie erreichte $0,7 \mathrm{~kg}$ Honig auf 1000 Brutzellen, dic Regression von Brutzellen und Honigproduktion der Töchter auf die Brutzellen der Mütter war sehr gering und nicht signifikant. Daher konnte die Fruchtbarkeit der Italiener-Königinnen, gemessen an der Zahl der Brutzellen, nicht als Kriterium für die Selektion zur Steigerung der Honigproduktion verwendet werden. Die Regression der Honigproduktion der Tochter-Königinnen auf die ihrer Mütter betrug $0,27 \pm 0,08$ und zeigt eine Heritabilität von 0,54. Das Selektionsdifferential für Königinnen (Durchschnitt aus $13 \mathrm{Jahren}$ ) betrug $17,5 \mathrm{~kg}$. Daher scheint die Auslese der Königinnen nach der Honigleistung ein wirksames Mittel gewesen zu sein, um die Honigproduktion der Italiener-Biene zu steigern.

\section{REFERENCES}

FARrar C.L., 1937. - The influence of colony populations on honey production. J. Agr. Res. 54 : 945 954.

Fresnaye J., 1963. - Les erreurs d'orientation des abeilles (dérive) dans le rucher moderne. Ann. Abeille. $6: 185-200$.

Louveaux J., 1967. - Les problèmes posés par la génétique et la sélection de l'abeille. Ann. Abeille, 10 : 213-252.

Pirchner F., Ruttner F. und Rutrner H., 1962. - Erbliche Unterschiede zwischen Ertragseigenschaften von Bienen. XI Congr. Ent. 1960, 2 : 501-516.

RUtTNER H. und F., 1972. - Untersuchungen über die Flugaktivität und das Paarungsverhalten der Drohnen. V. Drohnensammelplätze und Paarungsdistanz. Apidologie. 3 : 203-232.

SOLler M. and BAR-COHEN R. 1967. - Some observations on the heritability and genetic correlation between honey production and brood area in the honey bee. J. Apic. Res. $6: 37-43$. 